\title{
Pivoting academic skills support online: a critical reflection on practice
}

Julie Nolan

Edge Hill University

Helen Jamieson

Edge Hill University

Keywords: academic skills; online pivot; critical reflection; Covid-19.

\section{The challenge}

In response to Covid-19 in March 2020, universities across the higher education (HE) sector pivoted their teaching, learning and support online. As a team of Academic Skills Advisors (ASAs) at a northwest United Kingdom (UK) university who support students with a range of academic skills, including academic writing and information literacy, we too made the pandemic pivot. In March 2021 we needed to start planning for the coming year. In this paper we discuss our critical reflection on relocating our academic skills support fully online and consider how these reflections will help shape our future provision.

\section{The response}

We adopted Brookfield's critical reflection model (2017) - an evidence-based approach to frame our reflections. This model offered four lenses for critical reflection (Figure 1). 


\section{Figure 1. Brookfield's four lenses model (2017).}

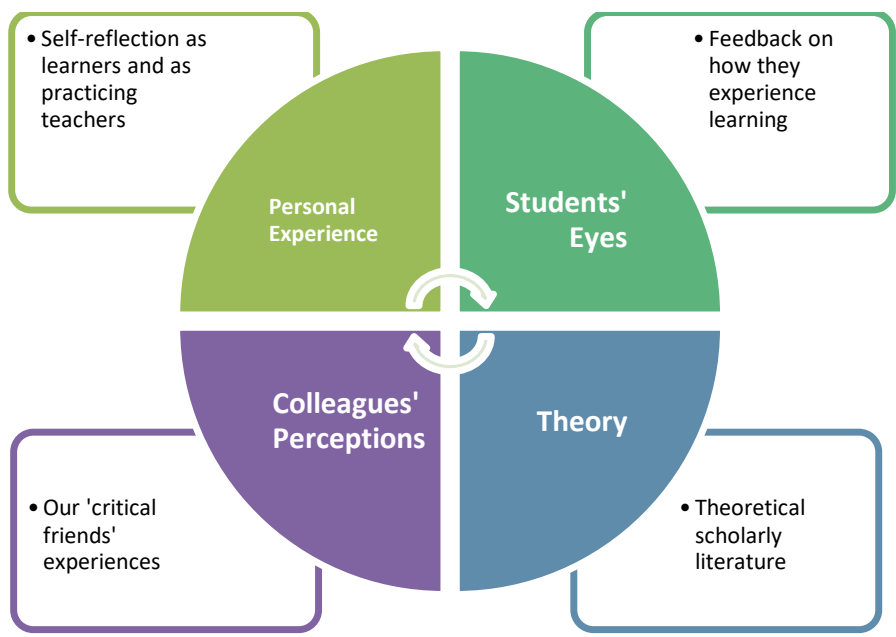

\section{Personal experience}

Brookfield (2017) argues that it is important to include personal stories or anecdotes in any critical reflection, and that reflection can be useful as a 'collective enterprise'. Six months after moving our academic skills support online, our ASAs reflected, both individually and collectively, on how their approach to the delivery of skills support had changed. Key considerations included:

- Difficulties measuring student engagement online.

- The challenge of balancing activities and interactions online.

- The importance of communities of practice and colleagues' support.

- A need to upskill the team (digital skills and learning technologies).

- Moving support created an opportunity to improve accessibility and promote an inclusive learning environment in some areas of provision.

- Impact on time and resource implications.

\section{Students' eyes}

Obtaining student feedback can be challenging; however, a student-facing evaluation framework was already embedded within our existing practice, and we were easily able to broaden our usual feedback mechanisms. As well as more formal mechanisms, informal 
student feedback received during appointments, webinars, via email and across our social media channels was also collated and synthesised. Whilst Brookfield (2017) argues that the most important pedagogic knowledge we need as practitioners is an awareness of how students experience learning, he also recognises the 'dangers of taking student definitions at face value'. Key findings, in addition to a general appreciation that support remained available and accessible, included:

\section{1-2-1 appointment feedback:}

- $100 \%$ satisfied with the structure and content of online appointments.

- $93.8 \%$ satisfied or very satisfied with the appointment being online.

- $25 \%$ would prefer in person, $25 \%$ would prefer online, and $50 \%$ would like both options to choose from.

\section{Webinar feedback:}

- Several students commented on the benefits of re-watching sessions.

- $81 \%$ agreed or strongly agreed that the webinar content stimulated their learning.

- $82 \%$ agreed or strongly agreed that the webinar was useful for their course.

\section{Colleagues' experiences}

As 2020 ended, we invited academic colleagues to feed back on our virtual support. Brookfield (2017) describes 'critical friends' as being at the heart of the reflective process. He suggests that talking to colleagues helps practitioners to 'check, verify or reframe assumptions' and 'offer multiple perspectives' (Brookfield, 2017).

Whilst we remain mindful that the overall 'gratitude' for continued support will have had an impact on associated feedback, key findings included:

- Online support had been 'flexible', 'accessible', 'well planned' and 'valuable to [their] students'.

- 'Facilitators [ASAs] had great personalities and presence, ... so important given the virtual nature of the sessions'. 
- Their 'students were fully engaged, and staff were very encouraging and supportive'.

- The option to receive support/content synchronously, asynchronously or via a combination of the two was welcomed, and this often led to further discussions around a 'combination' approach.

- Developmental feedback suggested including more 'activity' or 'practical tasks', to allow students to practise what they were learning (most notably around referencing).

\section{Theoretical literature}

Brookfield (2017) describes theory as a way to test our understanding and to combat 'group think' (Brookfield, 2017). Whilst a lot has been written about online learning as a concept, there is much less published and peer reviewed literature around pivoting academic skills support. What we discovered in the literature fell into five key themes which will help inform our future practice:

- Digital inequality: different levels of access to technology, equipment, software and hardware, and varying confidence in seeking support (JISC, 2020a; Lambie and Law, 2020; Nordmaan et al., 2020; Raaper and Brown, 2020).

- Misconceptions about digital skills: the assumption that students have the necessary skills and competencies for learning online and learning to navigate the different technologies and platforms, alongside the wide range of new terminology, can be confusing for students (Adedoyin and Soykan, 2020; JISC, 2020b; Lambie and Law, 2020; Watermeyer et al., 2021).

- Importance of student as partners: involving students in decision making processes ensures their digital experience delivers what they need and shapes the digital landscape for future students (JISC, 2020a; JISC, 2020b; Whelehan, 2020; Jackson, 2020; 2021).

- Inclusive learning design: whilst the addition of technology does not automatically improve learning design, content and presentation, it does provide an opportunity to consider doing things differently; therefore, it is vital to keep good pedagogy at the 
heart of learning design, with technology used to enhance (not drive) the learning experience (CAST, 2018; Adedoyin and Soykan, 2020; JISC, 2020a; JISC, 2020b; Neves and Hewitt, 2020; Nordmaan et al., 2020; Watermeyer et al., 2021).

- Creating a sense of belonging: the lack of a physical 'university space' impacts on students' self-discipline, wellbeing and sense of belonging; universities need to consider how to create a sense of community and belonging when delivering teaching and support online (Stadtfeld et al., 2019; Elmer et al., 2020; Hodges et al., 2020; Nordmaan et al., 2020; Raaper and Brown, 2020; Lederer et al., 2021; Pownall et al., 2021).

\section{Recommendations}

Brookfield's four lenses (2017) provided a robust framework for us to critically reflect on our pivot online successfully. This model enabled us to understand the challenges and implications faced by the ASAs, but equally the importance of having an established community of practice and supportive team ethos. We learned a lot about student preferences and expectations about their learning, which helped us clearly map out our future without making assumptions about students' needs. Receiving developmental feedback and advice from our academic colleagues, who had also moved fully online, was invaluable to our practice and delivery development. And through our evaluation and findings we can contribute to the gap in the literature on pivoting academic skills support online.

Other practitioners may wish to clearly map out an evaluation plan to ascertain what feedback they wish to gather, and from where, before embarking on this model. We would also recommend allowing ample time to synthesise and analyse the data.

\section{References}

Adedoyin, O.B. and Soykan, E. (2020) 'Covid-19 pandemic and online learning: the challenges and opportunities', Interactive Learning Environments, pp.1-13. 
Available at: https://doi.org/10.1080/10494820.2020.1813180 (Accessed: 18 October 2021).

Brookfield, S. (2017) Becoming a critically reflective teacher. $2^{\text {nd }}$ edn. San Francisco: Jossey-Bass, pp.61-77.

CAST (2018) The UDL guidelines. Available at: https://udlguidelines.cast.org/ (Accessed: 13 March 2021).

Elmer, T., Mepham, K. and Stadfeld, C. (2020) 'Students under lockdown: comparisons of students' social networks and mental health before and during the Covid-19 crisis in Switzerland', PLOS ONE, 15 (7). Available at: https://doi.org/10.1371/journal.pone.0236337 (Accessed: 12 January 2021).

Hodges, C., Moore, S., Lockee, B., Trust, T. and Bond, A. (2020) 'The difference between emergency remote teaching and online learning', Educause Review. Available at: https://er.educause.edu/articles/2020/3/the-difference-between-emergency-remoteteaching-and-online-learning (Accessed: 12 January 2021).

Jackson, A. (2020) 'The expectation gap: students' experience of learning during Covid-19 and their expectations for next year', WONKHE. Available at:

https://wonkhe.com/blogs/the-expectation-gap-students-experience-of-learningduring-covid-19-and-their-expectations-for-next-year/ (Accessed: 12 January 2021).

Jackson, A. (2021) 'The expectation gap II: students' experience of learning during Covid19 and their expectations for next year', WONKHE, 3 February. Available at: https://wonkhe.com/blogs/the-expectation-gap-ii-students-hopes-for-learning-andteaching-in-the-next-normal/ (Accessed: 13 March 2021).

JISC (2020a) Student digital experience insights survey 2020: UK higher education (HE) survey findings. Available at: https://www.jisc.ac.uk/sites/default/files/student-dei-hereport-2020.pdf (Accessed: 12 January 2021). 
JISC (2020b). Learning and teaching reimagined: change and challenge for students, staff and leaders. Available from: https://www.jisc.ac.uk/sites/default/files/ltr-reportchange-and-challenge-for-students-staff-and-leaders-aug-2020.pdf (Accessed: 12 January 2021).

Lambie, I. and Law, B. (2020) 'Teaching online during a pandemic: pedagogical skills transfer from face to face support to online synchronous support provision', Proceedings of the $1^{\text {th }}$ European Conference on e-learning, Glasgow, 28-30 October. Available at:

https://researchonline.gcu.ac.uk/ws/portalfiles/portal/42976118/Lambie I. Law B. 2020 Teaching online during a pandemic Pedagogical skills transfer from face to face support to online synchronous support provision.pdf (Accessed: 20 February 2021).

Lederer, A.M., Hoban, M.T., Lipson, S.K., Zhou, S. and Eisenberg, D. (2021) 'More than inconvenienced: the unique needs of U.S. college students during the Covid-19 pandemic', Health education \& behavior, 48(1), pp.14-19. Available at: https://doi.org/10.1177\%2F1090198120969372 (Accessed: 13 March 2021).

Neves, J. and Hewitt, R. (2020) Student academic experience survey 2020. Available at: https://www.hepi.ac.uk/wp-content/uploads/2020/06/The-Student-AcademicExperience-Survey-2020.pdf (Accessed: 12 January 2021).

Nordmaan, E., Horlin, C., Hutchinson, J., Murray, J., Robson, L., Seery, M.K. and MacKay, J.R.D. (2020) 'Ten simple rules for supporting a temporary online pivot in higher education', PLoS Comput Biol 16(10), e1008242. Available at: https://doi.org/10.1371/journal.pcbi.1008242 (Accessed: 12 January 2021).

Pownall, M., Harris, R. and Blundell-Birtill, P. (2021) 'Supporting students during the transition to university in Covid-19: 5 key considerations and recommendations', Psychology Learning and Teaching. Available at: https://doi.org/10.1177/14757257211032486 (Accessed: 18 October 2021). 
Raaper, R. and Brown, C. (2020) 'The Covid-19 pandemic and the dissolution of the university campus: implications for student support practice', Journal of Professional Capital and Community, 5 (3/4), pp.343-349. Available at: https://doi.org/10.1108/JPCC-06-2020-0032 (Accessed: 20 February 2021).

Stadtfeld, C., Vörös, A., Elmer, T., Boda, Z. and Raabe, I.J. (2019) 'Integration in emerging social networks explains academic failure and success', Proceedings of the National Academy of Sciences, 116(3), pp.792-797. Available at: https://dx.doi.org/10.1073\%2Fpnas.1811388115 (Accessed: 13 March 2021).

Watermeyer, R., Crick, T., Knight, C. and Goodall, J. (2021) 'Covid-19 and digital disruption in UK universities: afflictions and affordances of emergency online migration', Higher Education, 81(3), pp.623-641. Available at: https://doi.org/10.1007/s10734-020-00561-y (Accessed: 13 March 2021).

Whelehan, D.F. (2020) 'Students as partners: a model to promote student engagement in post-Covid-19 teaching and learning', AISHE, 12 (3). Available at: https://ojs.aishe.org/index.php/aishe-j/article/view/479 (Accessed: 12 January 2021).

\section{Author details}

Julie Nolan is Acting Head of Student Engagement: Library and Learning Services at Edge Hill University.

Helen Jamieson is Acting Head of Digital Learning Technologies: Library and Learning Services at Edge Hill University. 